\title{
How Cost Influences Uptake of Credit Cards in Kenya
}

\author{
Caroline Achieng Otieno ${ }^{1}$, Tobias Olweny ${ }^{2}$ \\ ${ }^{1,2}$ School of Business, Jomo Kenyatta University of Agriculture and Technology, P.O. Box 8895 -00200, Nairobi, Kenya
}

\begin{abstract}
There has been worldwide increase in the use of credit cards which are replacing currency as a method of payment. The objective of this study was to determine how cost influences the uptake of credit cards in Kenya. Descriptive survey design using questionnaires was adopted to collect data from selected credit card holders in five commercial banks operating in Nairobi County of Kenya. The study established that demographic factors such as age, marital status level of education and gross monthly income had strong positive correlation with cost variables in influencing uptake of credit cards, which was further explained through multiple regression model: $Y=\beta_{0}+\beta_{1} X_{1}+\beta_{2} X_{2}+\beta_{3} X_{3}+\beta_{4} X_{4}+\beta_{5} X_{5}+\varepsilon$. Cost was a key determinant of credit card uptake and the card holders saw use of credit cards as a way of reducing the need to carry cash and also brought financial independence. Uptake of credit card was also due to high cost of living and majority of the respondents were not satisfied with the high interest rates charged on credit card debts. The study recommended campaigns geared towards encouraging use of credit cards and further studies on how specific individual demographic factors influence uptake of credit cards in the Kenyan market.
\end{abstract}

Keywords: Credit Card, Card Holder, Card Issuer, Cost

\section{Introduction}

A credit card is a plastic card issued by a commercial bank or any other institution that allows the cardholder (user) to purchase goods and services on credit up to an agreed limit set at specific place where these cards are accepted [1]. The principle of a credit card is that the card provider lends the money to the cardholder (consumer) to be paid to the merchant, and later the cardholder pays on the agreed terms. The credit card offers consumers the benefit of acquiring and using goods and services without paying for them with cash, thus removing the burden of carrying cash. The credit card also offers consumers access to credit without having to go through elaborate paper work as is the case with a loan. Despite these benefits, credit card ownership and usage have been associated with increased consumer debt and unplanned spending [2].

Credit cards provide a convenient method of completing transactions, enable consumers coordinate the timing of consumption and the flow of income and credit cards are a convenient source of credit for both consumers and merchants [3]. Credit cards offer the convenience of cashless transactions and also allow for purchases over the telephone and, via the internet. The challenges attributed to credit card usage include; deepening debt since consumers' purchase goods on credit with the intention of paying in the future, Overuse since revolving credit makes it easy to spend beyond your means, credit card fraud, unexpected fees which ranges between $5-10 \%$ of the transaction amount when drawing cash from a merchant or Automated Teller Machine (ATM) and increased paper work since you have to save the receipts and check them against the statement every month.

The cost in relation to the price determines whether to have a credit card or not. The interest charged for use of credit card is a determining factor in its uptake while the price charged on the goods and services purchased by use of the card, determine the level of card use. The card provider avails the use of credit cards at cost to the cardholder referred as interest rates. The cardholder enjoys the use of credit cards and pays, the amount utilized at the end of the period as stipulated in the credit card agreement and is meant to equate the future satisfaction with the present satisfaction [4].

The rate of interest levied on credit cards determine the uptake as one need to compare the benefits accruing by use of card in relation to the value of his/her money both at present and in future [5]. Card providers and leading services providers enter into partnership, that enable the cardholder enjoy services at discounted rates. These discounts reduce the price of goods and services to the cardholder and in turn encourages one to have a credit card in order to tap benefits derived from the card use.

\subsection{Statement of the Problem}

Globally, credit card ownership and usage have increased substantially in recent decades. This trend reflects the growing popularity of the credit card as a preferred mode of payment for goods and services in lieu of cash, cheques and other forms of payment [6]. Credit card ownership and usage are associated with increased consumer debt and unplanned spending and research findings show that debt associated with credit card usage has been on the rise and that credit card related debt account for a substantial share of household spending. This has raised concern amongst policymakers regarding the potential adverse effects on consumers and the economy. In this regard, this study sort to establish how cost influence uptake of credit cards in Kenya.

\section{Literature Survey}

\subsection{Empirical Study}

A study conducted by Ausubel [7] on household borrowing behavior through the use of credit cards, with a view of ascertaining their borrowing behavior identified three 


\section{International Journal of Science and Research (IJSR) \\ ISSN (Online): 2319-7064}

Index Copernicus Value (2013): 6.14 | Impact Factor (2015): 6.391

puzzles: First, use of high rather than lower interest credit cards for borrowing purposes. This was mainly due to failure of consumers to anticipate the likelihood that they had to pay interest on the outstanding credit card balances. The second puzzle arose from co-existence in household portfolio of credit cards and the accumulated non liquid assets reaching high especially for people with the age of between 50-59 years. The third puzzle, which is termed as debt revolver arose from the co-existence of high interest credit card debt and low interest liquid assets that could be used to repay at least part of it. This tendency has also been documented in data by Morrison [8]. The study failed to address how debt revolvers, are unable to borrow through the use of credit cards yet able to withdraw cash by use of credit cards. Munro and Hirt [9] found that there were significant differences between demographic factors such as race, and academic standing with credit card payment practices. Kaynak, Kucukemiroglu and Ozmen [10] studied credit card users in Turkey and found that income and education was positively related to card usage while gender had a negative influence on card usage.

\subsection{Theories of Credit Card Uptake}

\subsubsection{Liquidity Preference Theory}

Liquidity preference theory was developed by Keynes during the early 1930's following the great depression with persistent unemployment for which the quantity theory of money had no answer to economic problems in the society [4]. According to this theory, it is the preference to have an equal amount of cash rather than of claim against others. According to Keynes (1936), interest is purely a monetary phenomenon where everybody wants to hold his or her assets in the most liquid form and interest is the reward made to people for surrendering their liquidity preference. It is the price paid to the wealth holders for rendering their liquid funds immobile. Ankintoye [11] observed that, income velocity is not constant but its variability is influenced by the level of interest rates, liquidity preferences, the change in income, the scale of anticipated expenditures, availability of money substitutes and the number of non-bank financial institutions. Keynes (1936), distinguished three motive for holding money balances: the transactions motive-to bridge the gap between receipt of income and planned expenditures; the precautionary motive-to provide a reservoir of purchasing power that can be used to finance unanticipated expenditures, and the speculative motive-to satisfy the desire to hold wealth in the most liquid form if one express interest rates on alternative assets to rise, thereby causing capital losses. The transactions demand for money relates to the need for cash balanced and to meet current assets and business transaction [12].

\subsubsection{The Loanable Funds Theory (classical theory of interest rate)}

Loanable funds theory explains the determination of interest in terms of demand and supply [4]. According to this theory, the rate of interest is the price of credit which is determined by the forces of demand and supply. Also according to Amadi and Akani, [13] the loanable funds theory of interest at any time represents an equilibrium price at which the demand for credit from those who prefer to have the interest.
However, Tokunbo [14] posits that, the demands for loanable funds is from three sources, Government, businessmen and consumers, who use them for purpose of investment in the economy.

\section{Research Methodology}

\subsection{Study Population}

This study was conducted among credit card holders within credit card centers of five commercial banks within Nairobi County of Kenya. The target population in this study comprised of all card holders within the 42 commercial banks that operate in Nairobi County, Kenya from where five commercial banks were selected for the study based on their asset value. Each of the five banks, classified as large-sized with asset value greater than USD 150 million, provided a total of 30 credit card holders for the study and the total sample was thus 150 credit card holders. According to Gay [15], at least $10 \%$ of the population is a good representation where the population is large and $20 \%$ where the population is small.

\subsection{Sampling Design}

Probability sampling was used to select the participants for this study. Probability sampling refers to sampling design in which all the study units are known and has equal chances of being selected and included in the sample size. The probability sampling was justified because the population was large and this method is known to provide accurate information since a reasonable number of objects are selected [16].

\subsection{Research Design and Methodology}

The study adopted descriptive survey design and utilized questionnaires to collect data. Descriptive survey design was appropriate because it involved collecting data in order to test hypothesis or questions concerning the current status of subjects of the study. It is used to test attitudes and opinions about events, individuals or procedure [15]. According to Orodho [17], descriptive survey designs are used in preliminary and exploratory studies to allow researchers to gather information, summarize, present and interpret for the purpose of clarification. The purpose of descriptive research is also to determine and report the way things are [16]. Descriptive survey research is intended to produce statistical information about aspects of education that interest policy makers and educators [18].

Open-ended and closed-ended self-administered questionnaires were issued to sample respondents. The openended questions were used to elicit honest, personal comments from respondents [19] and these questions probed the respondent's perceptions regarding the research questions. The researcher distributed and allowed the respondents some time to respond to the questions before collecting them for analysis. 


\section{International Journal of Science and Research (IJSR)}

ISSN (Online): 2319-7064

Index Copernicus Value (2013): 6.14 | Impact Factor (2015): 6.391

\section{Data Presentation and Analysis}

\subsection{Demographic features of respondents}

Majority of the respondents were female $(60 \%)$ and single (40\%). Most of the study respondents were employees in the public service and majority (40.7\%) were aged 31-40 years. $60 \%$ of the study respondents were from households of 1-3 heads while households with more than 9 members was represented by $6.7 \%$ of the respondents. On the basis of education level, majority of the respondents had undergraduate degree (46.7\%) while minority of them $(3.3 \%)$ had primary level of education. $40.7 \%$ of the respondents had been banking for $2-5$ years while $86.7 \%$ had only a single credit card. $13.3 \%$ of the respondents had two credit cards while $46.7 \%$ of the respondents had used credit cards for 2-5 years. A study conducted on knowledge level among individuals on use of credit cards suggested that women were the majority card holders and understood their credit cards better than male counter parts [20]. Hira et.al., [21] found out that female married and older students understood more about financial and credits followed by the single female who were in need of being more financially independent. Kaynak and Harcar [22] found out that credit card companies issue their cards to a pre-selected group of individuals like those who have substantial repayment capacity, well educated and clients at their banks.

\subsection{The relationship between cost and uptake of credit card}

The study respondents were asked on their opinion regarding reasons for using credit cards. Majority $(86.7 \%)$ agreed that credit card brings financial independence (Table 1) and this enable them to buy goods and services any time they are in need and reduces the need to carry cash around. This reduced risks associated with carrying cash and these findings are in agreement with the study by Nzotta [23] that revealed that demand and supply for funds by consumers determine their need to transact for different motives at different time.
Table 1: Reasons for using credit cards

\begin{tabular}{|c|c|c|}
\hline & \multicolumn{2}{|c|}{$\begin{array}{c}\text { Percentage of } \\
\text { respondents }\end{array}$} \\
\hline Question & Agree & Disagree \\
\hline Do credit cards bring financial independence? & 86.7 & 13.3 \\
\hline Do credit cards reduce need to carry cash? & 90 & 10 \\
\hline
\end{tabular}

Majority of card holders were influenced to acquire credit cards by high cost of living (33.3\%) and convenience (20\%) as shown in Figure 1. A study by Ausubel [7] conducted on 244 households to ascertain their borrowing behaviour found that many households preferred to have a credit card to ensure they are able to access goods and services due to the rising cost of living.

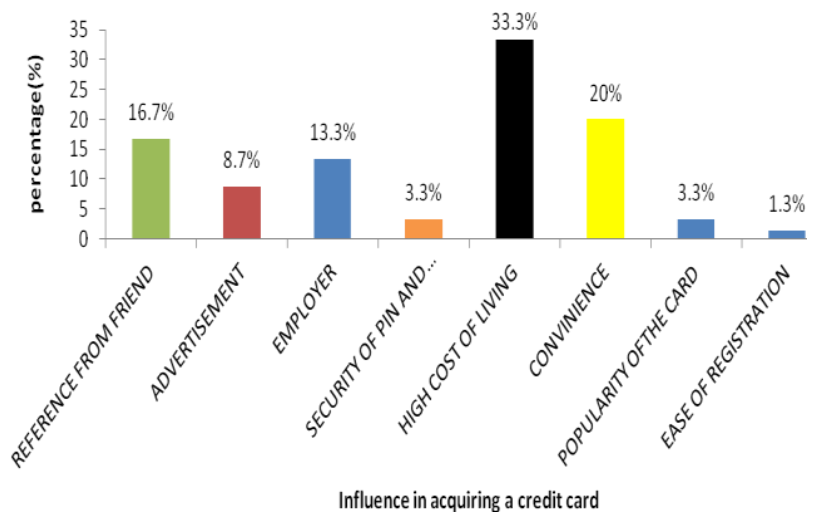

Figure 1: Factors influencing acquisition of credit cards

The study respondents were also asked on their levels of satisfaction regarding interest rates charged on credit cards and use of credit cards to purchase high priced and discounted goods and the findings are as shown in Figure 2. $80 \%$ of the card holders were satisfied with purchasing discounted goods while only $20 \%$ of the study respondents were satisfied with purchasing high priced commodities. $53.3 \%$ of the respondents were not satisfied with the interest rates charged on credit cards while $26.7 \%$ were less satisfied with interest rates charged (Figure 2). A study by Morrison [8] concluded that cardholders are aware they are paying more for their credits cards and this gives them reasons to buy discounted goods.

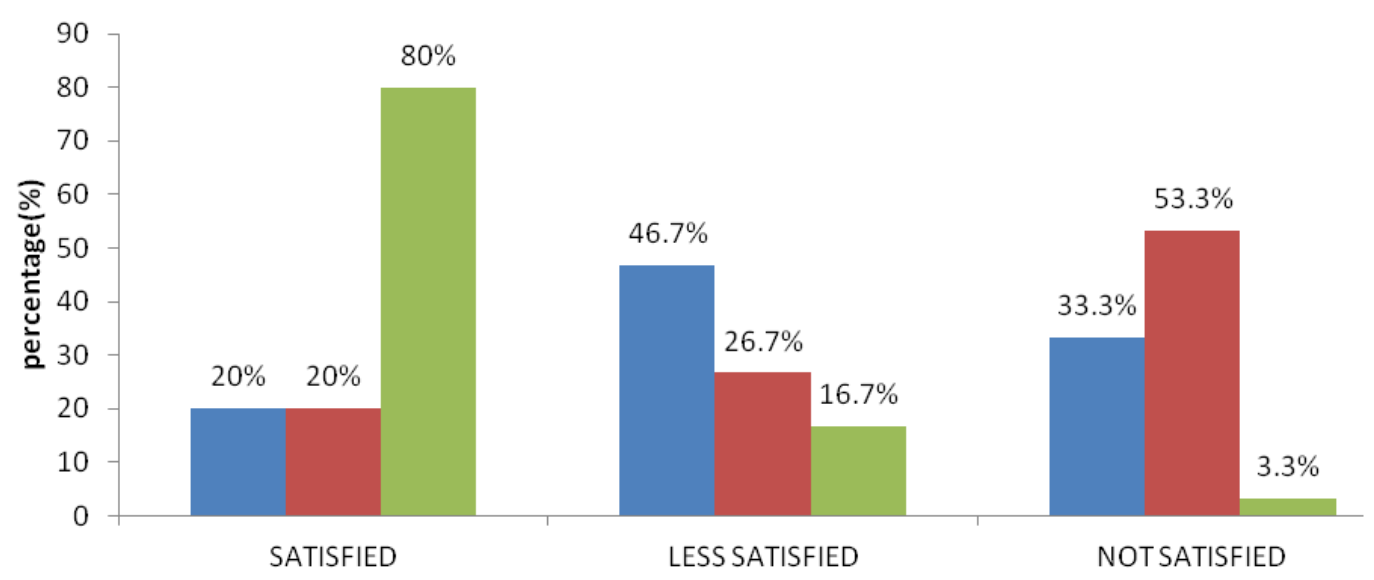

a satisfied with interest rate charged $\square$ purchasing high priced goods $\square$ purchasing discounted goods

Figure 2: Level of Satisfaction on use of credit cards 


\section{International Journal of Science and Research (IJSR) \\ ISSN (Online): 2319-7064}

Index Copernicus Value (2013): 6.14 | Impact Factor (2015): 6.391

\subsubsection{Factors Hindering Use of Credit Cards}

High interest rates charged on credit cards was considered as a factor hindering use of credit cards by $39.30 \%$ of the study respondents while $40.70 \%$ of the study respondents revealed that they got discouraged to use credit card due to fraud (Figure 3). These findings are in agreement with a study conducted by Munro [24] on credit cards and fraud that revealed that fraud has become a major reason for card holders' discouragement to use credit cards followed by high interest rate charged on the cards.

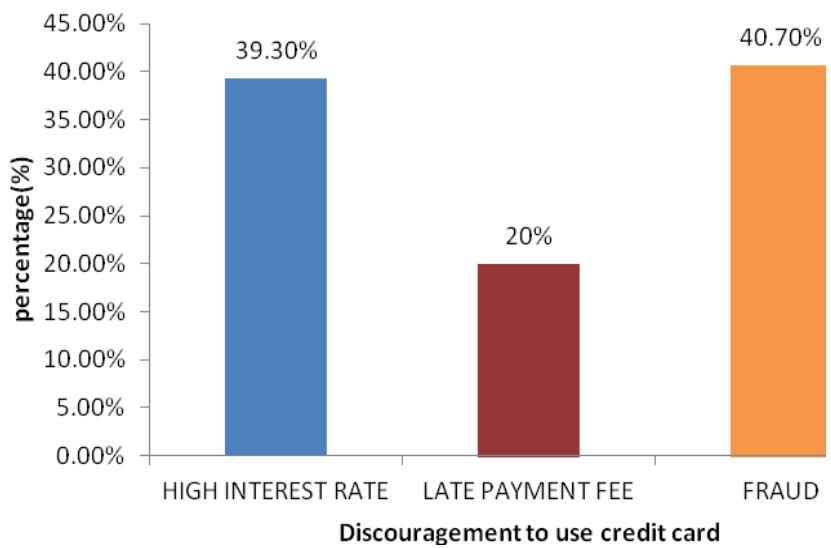

Figure 3: Reasons for Discouragement to use credit cards

In spite of the challenges encountered while using credit cards, $60 \%$ of the respondents indicated that they used their credit cards weekly while $16.7 \%$ used the cards on daily basis. $10 \%$ of the respondents used their credit cards monthly while $6.6 \%$ of the respondents used the credit cards either annually or biannually.

\subsection{Correlation between Demographic Factors and Cost Variables}

Pearson correlation coefficients were calculated and used to establish the relationships between the various demographic factors (independent variables) and variables associated with cost that influence uptake of credit cards. The association between demographic factors such as age, marital status, level of income and gross monthly income and various cost variables associated with uptake of credit cards such as reduced need to carry cash, financial independence and preferred mode of payment for credit card debts both revealed strong positive correlations that were statistically significant. The highest correlation existed between marital status and financial independence brought about by use of credit cards $\left(r_{(150)}=0.883, p=0.016\right)$ while the lowest correlation existed between level of education and preferred mode of payment for credit card debts ( $\mathrm{r}_{(150)}=0.589$, $\mathrm{p}=0.044$ ). However, overall, all these were strong positive correlations that supported the association between demographic factors and cost variables and their overall influence on uptake of credit cards. There was also significant positive correlation between duration of banking and financial independence brought about by use of credit $\operatorname{cards}\left(r_{(150)}=0.862, p=0.015\right)$, regularity in use of credit card $\left(r_{(150)}=0.822, p=0.019\right)$, reduced need of carrying cash $(\mathrm{r}$ $(150)=0.828, p=0.017)$, order of preferred security for a credit card $\left(\mathrm{r}_{(150)}=0.811, p=0.028\right)$, type of credit card preferred $(\mathrm{r}$ $\left.{ }_{(150)}=0.813, p=0.020\right)$, and preferred mode of payment $\left(\mathrm{r}_{(150)}\right.$ $=0.657, p=0.045)$. Strong positive correlation also existed between duration of using a credit card and financial independence brought about by use of credit cards $\left(r_{(150)}=\right.$ $0.832, p=0.018)$, regularity in use of credit card $\left(r{ }_{(150)}=\right.$ $0.871, p=0.020)$, reduced need to carry cash $\left(\mathrm{r}_{(150)}=0.830\right.$, $p=0.019)$ and preferred mode of payment for credit card $\operatorname{debts}(\mathrm{r}(150)=0.692, p=0.046)$.

\subsection{Multiple Regression Analysis}

Demographic factors such as gender, age, level of education, marital status and gross monthly family income were evaluated using multiple regression analysis, including analysis of variance (ANOVA)to predict their influence on the various factors that affect uptake of credit cards. The beta coefficients from multiple regression analysis are as shown in Table 2. The ANOVA using combination of variables (gender, marital status, age, level of education and gross family income) to predict on whether credit card brings about financial independence showed that, $\mathrm{F}(5,144)=133.318$, $p<0.001$. The contribution of these demographic variables were also significant with respect to how credit cards reduced the need to carry cash $\left(\mathrm{F}_{(5,144)}=105.308, \mathrm{p}<0.001\right)$; and the preferred mode of payment for credit card debts $\left(\mathrm{F}_{(5,144)}=\right.$ $25.685, \mathrm{p}<0.001)$.

The multiple regression equations can be represented by:

$Y=\beta_{0}+\beta_{1} X_{1}+\beta_{2} X_{2}+\beta_{3} X_{3}+\beta_{4} X_{4}+\beta_{5} X_{5}+\varepsilon$

Where:

$\mathrm{Y}=$ Dependent variable

$\mathrm{X}_{1}=$ Gender

$\mathrm{X}_{2}=$ Age

$\mathrm{X}_{3}=$ Level of education

$\mathrm{X}_{4}=$ Marital status

$\mathrm{X}_{5}=$ Gross monthly income

$\beta_{0}=$ Constant

$\beta_{1} \ldots \beta_{5}=$ Beta values

$\varepsilon=$ Error term

\section{Hence for;}

i. Financial independence brought about by use of credit cards

$\mathrm{y}=0.096+0.000 \mathrm{X}_{1}+0.283 \mathrm{X}_{2}+0.014 \mathrm{X}_{3}+0.466 \mathrm{X}_{4}+$ $0.179 \mathrm{X}_{5}+0.164$

\section{ii. Card reduces need to carry cash due to use of credit cards \\ $\mathrm{y}=0.325+0.009 \mathrm{X}_{1}+0.196 \mathrm{X}_{2}-0.132 \mathrm{X}_{3}+0.409 \mathrm{X}_{4}+$ $0.436 \mathrm{X}_{5}+0.172$}

\section{iii. Preferred mode of payment for credit card debts}

$\mathrm{y}=0.666+0.000 \mathrm{X}_{1}+0.351 \mathrm{X}_{2}-0.146 \mathrm{X}_{3}+0.328 \mathrm{X}_{4}+$ $0.168 \mathrm{X}_{5}+0.123$

Marital status, age, level of education and gross family income both had statistically significant $(\mathrm{p}<0.05)$ contribution towards the view that credit cards bring financial independence when all the five variables were included. However, contribution of gender was not statistically significant $(\mathrm{p}>0.05)$. Marital status, age, level of education

\section{Volume 5 Issue 6, June 2016} www.ijsr.net 


\section{International Journal of Science and Research (IJSR) \\ ISSN (Online): 2319-7064 \\ Index Copernicus Value (2013): 6.14 | Impact Factor (2015): 6.391}

and gross family income both had statistically significant $(\mathrm{p}<0.05)$ contribution towards the view that credit cards bring financial independence when all the five variables were included. However, contribution of gender was not statistically significant $(\mathrm{p}>0.05)$. Gender, age and gross monthly family income both had statistically significant $(p<0.05)$ contribution towards the type of security of credit cards preferred by the credit card holders when all the five variables were included. However, contribution of level of education and marital status was not statistically significant ( $p>0.05)$. Age, marital status and gross monthly family income both had statistically significant $(\mathrm{p}<0.05)$ contribution towards the preferred mode of payment for credit card debts by credit card holders when all the five variables were included. However, contribution of level of education and gender was not statistically significant ( $p>0.05$ ). The adjusted $\mathrm{R}^{2}$ values (Table 3 ) in all the instances were large, signifying that the variance relating credit cards and the various demographic variables could well be explained by the regression models and according to Cohen et al., [19], these were large effects.

\section{Conclusions}

The study established that cost was a key determinant of credit card uptake and the card holders saw use of credit cards as a way of reducing the need to carry cash and also brought financial independence. Uptake of credit card was also due to high cost of living and majority of the respondents were not satisfied with the high interest rates charged on credit card debts. The study recommend campaigns geared towards encouraging use of credit cards and further studies on how specific individual demographic factors influence uptake of credit cards in the Kenyan market.

Table 2: Beta Coefficients for Demographic factors and dependable variables

\begin{tabular}{|c|c|c|c|c|c|c|}
\hline \multirow[t]{2}{*}{ Dependable variables } & \multirow[t]{2}{*}{ Demographic factors } & \multicolumn{2}{|c|}{$\begin{array}{c}\text { Unstandardized } \\
\text { Coefficients }\end{array}$} & \multirow{2}{*}{$\begin{array}{c}\text { Standardized } \\
\text { Coefficients } \\
\text { Beta }\end{array}$} & \multirow[b]{2}{*}{$T$} & \multirow[b]{2}{*}{$p$ value } \\
\hline & & $\boldsymbol{B}$ & Std. Error & & & \\
\hline \multirow{6}{*}{$\begin{array}{l}\text { Card brings financial } \\
\text { independence }\end{array}$} & Constant & 0.096 & 0.164 & & 0.584 & 0.560 \\
\hline & Gender & 0.001 & 0.056 & 0.000 & .013 & 0.990 \\
\hline & Age & 0.244 & 0.082 & 0.283 & 2.987 & 0.003 \\
\hline & Level of education & 0.011 & 0.095 & 0.014 & 0.119 & 0.905 \\
\hline & Marital status & 0.283 & 0.054 & 0.466 & 5.249 & 0.000 \\
\hline & Gross income monthly & 0.060 & 0.050 & 0.179 & 1.215 & 0.226 \\
\hline \multirow{6}{*}{$\begin{array}{l}\text { Card reduces need to carry } \\
\text { cash }\end{array}$} & Constant & 0.325 & 0.172 & & 1.887 & 0.061 \\
\hline & Gender & 0.013 & 0.059 & 0.009 & 0.220 & 0.826 \\
\hline & Age & 0.161 & 0.086 & 0.196 & 1.874 & 0.063 \\
\hline & Level of education & -0.103 & 0.100 & -0.132 & -1.028 & 0.306 \\
\hline & Marital status & 0.237 & 0.057 & 0.409 & 4.185 & 0.000 \\
\hline & Gross income monthly & 0.140 & 0.052 & 0.436 & 2.687 & 0.008 \\
\hline \multirow{6}{*}{$\begin{array}{l}\text { Preferred mode of payment } \\
\text { for credit card debts }\end{array}$} & Constant & 0.666 & 0.123 & & 5.400 & 0.000 \\
\hline & Gender & 0.000 & 0.042 & 0.000 & -.006 & 0.995 \\
\hline & Age & 0.131 & 0.061 & 0.351 & 2.143 & 0.034 \\
\hline & Level of education & -0.052 & 0.072 & -0.146 & -.723 & 0.471 \\
\hline & Marital status & 0.087 & 0.041 & 0.328 & 2.142 & 0.034 \\
\hline & Gross income monthly & 0.025 & 0.037 & 0.168 & 0.659 & 0.511 \\
\hline
\end{tabular}

Table 3: Regression Model Summary Showing $\mathrm{R}^{2}$ Values

\begin{tabular}{|c|c|c|c|}
\hline Model & $R^{2}$ & Adjusted $R^{2}$ & Std error of estimate \\
\hline Financial independence of credit cards & 0.822 & 0.816 & 0.336 \\
\hline Credit card reduces need to carry cash & 0.785 & 0.778 & 0.353 \\
\hline Preferred mode of payment for credit card debts & 0.471 & 0.453 & 0.252 \\
\hline
\end{tabular}

Predictors: (Constant): gross monthly income, gender, marital status, age, level of education

\section{References}

[1] Ogony, J.E. (2005). Factors affecting use or non-use of plastic money and attitudes towards plastic money. Standard chartered bank, Nairobi.

[2] Norum, P. S. (2008). The role of time preference and credit card usage in compulsive buying behaviour. International Journal of Consumer Studies, 32, 269275

[3] Lee, K. Y. \& Toh, J. (1995). 20-Day Grace . The Star.
[4] Jhingan, M.L. (2005). Money banking international trade and public finance. India: Vrinda Publications [P] Ltd.

[5] Ogwuma, P.A. (2008). The control of the monetary and banking system. 20(2).

[6] Abdul-Muhmin, Alhassan G., \& Umar, Yakubu A. (2007). Credit card ownership and usage behavior in Saudi Arabia: The impact of demographics and attitudes towards debt. Journal of Financial Services Marketing, 12(3), 219-235

[7] Ausubel L. (2001). The failure of Competition in the Credit cards Market. American Economic Review, 8081

\section{Volume 5 Issue 6, June 2016} www.ijsr.net 
[8] Morrison (2005)

[9] Munro, J. \& Hirt, J. B. (2005). Credit Cards and College Students: Who Pays, Who Benefits?. Journal of College Student Development, 39 (1): 51-57.

[10] Kaynak, E., Kucukemiroglu, O. and Ozmen, A. (1995). Correlates Credit Card Acceptance and Usage in an Advanced Developing Middle Eastern Country. Journal of Services Marketing, 9(4): 54-63.

[11] Ankintoye, I.R. (2000). Investment decision: Concepts, analysis management. Lagos: Unique Educational Publishers.

[12] Okpara G.C. (2010) A Diagonosis of the Determinants of Dividend Pay-Out Policy in Nigeria:A Factor Analytical Approach. American Journal of Scientific Research Issue 8.pp57-67

[13] Amadi, S. N. \& Akani, W. H. (2005). Interest rate and private domestic investment in Nigeria (1993-2004). Niger Delta University Press.

[14] Tokunbo, Z. (2005). Liquidity management in the Nigeria economy. Supruasfied Publishers.

[15] Gay, L.R., Mills, G.E. \& Airasian, P.W. (2012). Educational Research. Competencies for Analysis and Applications. (10th Edition). Columbus. Merrill.

[16] Mugenda, O.M. \& Mugenda, A.G. (2003). Research methods: quantitative and qualitative approaches. Nairobi: Acts Press.

[17] Orodho, J. A. (2004). Techniques of Writing Research Proposals and Reports in Education and Social Sciences. Nairobi. Masda Publishers.

[18] Gall, M.D., Gall, J.P. \& Borg, W.R. (2006). Education Research: An Introduction. $8^{\text {th }}$ Ed. New York: Longman.

[19] Cohen, L, Manion, L. \& Morrison, K. (2000). Research methods in education (5th edition). London: Routledge Falmer.

[20] Armstrong, G. (2002) Competition in Two Sided Markets. Rand Journal of economies 37 (3): 668-669

[21] Hira et.al., (2004)

[22] Kaynak, E., \& Harcar, T. (2001). Consumers' attitudes and intentions towards credit card usage in an advanced developing country. Journal of Financial Services Marketing, 6(1), 24-38.

[23] Nzotta, S.M. (2004). Money, banking and finance: Theory and practice. Revised Edition. Owerri: Husdon-Judge Publication.

[24] Munro, J. \& Hirt, J. B. (2005). Credit Cards and College Students: Who Pays, Who Benefits?. Journal of College Student Development, 39 (1): 51-57.

\section{Author Profile}

Caroline Achieng Otieno is a Master of Business Administration Scholar with profound interest in Finance and Accounting at Jomo Kenyatta University of Agriculture and Technology (JKUAT), School of Business.

Dr. Olweny Tobias is a Lecturer, School of Business, Jomo Kenyatta University of Agriculture and Technology (JKUAT). 